\title{
The Influence of Semantic and Pragmatic Factors in Wason's Selection Task: State of the Art
}

\author{
María Dolores Valiña, Montserrat Martín \\ Department of Social Psychology, Basic Psychology and Methodology, University of Santiago de Compostela, \\ Santiago de Compostela, Spain \\ Email: mdolores.valina@usc.es, montserrat.martin@usc.es
}

Received 12 April 2016; accepted 24 June 2016; published 27 June 2016

Copyright $@ 2016$ by authors and Scientific Research Publishing Inc.

This work is licensed under the Creative Commons Attribution International License (CC BY). http://creativecommons.org/licenses/by/4.0/

c) (7) Open Access

\begin{abstract}
One of the cognitive processes, which has generated more research within the framework of the Psychology of thinking, is human reasoning. Throughout the history of the Psychology of reasoning, one of the experimental tasks most frequently used to study how subjects reason, and why they make mistakes, is the Wason's selection task or the four card problem (Wason, 1966, 1968). This work presents the current state of the experimental research on this task, using as a common thread the empirical studies which have highlighted the plasticity of reasoning towards semantic and pragmatic factors.
\end{abstract}

\section{Keywords}

Thinking, Reasoning, Conditional Reasoning, Wason's Selection Task

\section{Introduction}

One of the principal ways in the study of human thinking is the cognitive approach, within the framework of the information processing paradigm. In general terms, Cognitive Psychology aims to study the human cognitive system, its organization and functional principles, in order to explain the human behaviour (Valiña \& Martín, 2015).

One of the cognitive processes, which has generated the most research within the framework of the Psychology of thinking, is human reasoning (see Evans, 2011; Evans \& Frankish, 2009; Martín \& Valiña, 2003, for a historical perspective on the study of thinking). Peter Wason (1924-2003) suggested many of the topics which have been the focus of attention of Cognitive Psychology researchers for the last fifty years. Among his first works is one of the experimental tasks which has generated the most research in the history of the Psychology of 
reasoning: the Wason's selection task or the four card problem (Wason, 1966, 1968).

The task involves presenting the subjects with four cards which have a number (odd or even) written on one side and a letter (vowel or consonant) on the other side. Immediately afterwards, a conditional rule is presented: "If a card has a consonant on one side then it has an odd number on the other side". The subjects had to say which card or cards they must turn over in order to decide whether the rule is true or false.

Logical analysis indicates that conditional statement included in the task should be interpreted as a material implication and, therefore, the correct answer is the selection of the antecedent of the rule ("p") and the negation of its consequent ("not-q"). The results of this original abstract version indicated that less than $10 \%$ of subjects answered correctly. Furthermore, they systematically committed one of the following mistakes: they either selected the card which represented the antecedent of the rule (verification bias: Wason, 1968) or they selected the antecedent and the consequent of the same (matching bias: Evans, 1972, 1998). What are the reasons why intelligent adult subjects fail to solve it?

The selection task is a meta-inference problem which requires the understanding of a conditional "if... then", and the formulation and verification of hypotheses. On one hand, research on the conditional has reflected the polysemic and ambiguous character of this type of statement (Byrne \& Johnson-Laird, 2009; Nickerson, 2015); on the other hand, hypothetical thinking is limited (Evans, 2007). In this sense, research with the selection task has tried to determine what factors can modulate both the understanding of the conditional rule included in the problem, as well as the limits of hypothetical thinking. The first factor studied was the abstract nature of the original task.

\section{First Explanations on the Task: The Thematic Facilitation Effect}

The first results obtained by Peter Wason lead him to present the human subject as a person who seemed irrational. In this way, "much of Wason's work became controversial because it apparently showed people as illogical or irrational" (Evans \& Johnson-Laird, 2003: p. 180).

The early investigations focused the difficulty of the task on the abstract nature of the rule presented. With this hypothesis, empirical studies were begun to be designed in which the content was manipulated, ratifying the existence of a thematic facilitation effect (Wason \& Johnson-Laird, 1972). Consequently, when the task included a concrete or thematic content, the subjects selected the correct cards more frequently than with those which had abstract content (Wason \& Shapiro, 1971 or Johnson-Laird, Legrenzi, \& Legrenzi, 1972. See Evans, Newstead, \& Byrne, 1993: Chapter 4, for a review on the history of the thematic facilitation effect; see also Martín, Valiña, Seoane, \& Leirós, 2008).

The hypothesis of thematic content facilitation was maintained until the end of the 1970's. Specifically, in 1979, Manktelow and Evans, using specific content with an arbitrary relationship ("If I eat haddock then I drink gin”), did not register any improvement in performance with respect to the original abstract version. According to the authors, the facilitation registered in the previous thematic versions could be related to the activation of the correct counterexample from the memory. In this sense, different researchers have highlighted the role of memory in performance with the selection task as one of the principal determiners of the content effect (see Feeney \& Thompson, 2014, for a recent publication on the relationships between memory and reasoning).

One of the thematic versions which registered a good performance, was designed by Griggs and Cox (1982): the "drinking age rule". In this task, the subjects had to imagine that they were police officers on duty. Their jobs were to ensure that people conform the rule: "if a person is drinking beer, then the person must be over 19 years of age". The key to the results was not the thematic content, but the intra-experimental relationship between content and experience. This forms the basis of the "memory cueing hypothesis" proposed by the authors.

Since Peter Wason's failure in the original version of the problem, other versions of the selection task were designed which, on some occasions, differed substantially from the original abstract one, without this being contemplated on an experimental level. Some of these will be reviewed hereinafter.

\section{Different Versions of the Selection Task or Different Selection Tasks?}

\subsection{The Deontic Selection Task}

One of the first thematic versions in which the facilitation effect was registered, included a postal rule (JohnsonLaird et al., 1972). In this work subjects were asked to imagine that they were post office workers sorting letters 
and testing the rule: "If a letter is sealed then it has a 50 lira stamp on it". They were given the following instruction: "to find out whether or not they violate the rule" (p. 397). According to the authors, the content of the problem improved the understanding of its logical structure. However, some changes had been included in this version with respect to the original, which could be key to explaining the results obtained, and that were not contemplated at that time. Later empirical research reflected the influence on reasoning of variables such as the inclusion of the task in a scenario (see for example Margolis, 1987 or Martín, Valiña, \& Evans 1999) or the type of experimental instructions the subjects received (Griggs, 1984; Griggs \& Jackson, 1990; Valiña, Seoane, Ferraces, \& Martín, 1995, 1998; Yachanin, 1983, 1986; Yachanin \& Tweney, 1982, among others).

Directly related to the scenario and the instructions, the importance of the deontic character of the statement as opposed to the indicative character of the original version was considered. In effect, most of the thematic versions in which facilitation had been registered, were contextualized in scenarios and included deontic statements. In these versions, the subjects' ability to make inferences about violations of rules made by the authorities or persons in charge in order to obtain benefits or avoid costs was analysed (see Evans \& Over, 1996: Chapter 4; Manktelow \& Over, 1995; or Beller, 2010, for a review of deontic reasoning). In general, deontic conditionals express obligation or permission and include explicitly or implicitly deontic modal terms such as "should", "must", etc. In one indicative version, the subjects are asked to falsify the rule while in deontic versions they are required to find violations. In this sense, they could be considered to be "two distinct forms of the Wason's selection task: indicative and deontic, depending on which kind of conditional and instructions is employed" (Evans \& Over, 1996: p. 71).

The first to consider the question of the deontic nature of the selection task were Manktelow and Over (1991). The authors designed a research in which the subjects reasoned with the rule "if you tidy up your room, then you may go out to play". Half of the subjects were instructed to imagine they were a boy who had been given the rule by his mother and were asked to indicate which cards had to be turned over to determine whether the mother had broken the rule. The other half of the subjects were instructed to take the view of the mother and were asked to determine whether the son had broken the rule. According to the authors, this type of conditional statement has two parts: an agent and an actor, and each of them includes different preferences, which the selected cards will modulate ("p y not-q" for the "child" and "not-p and q" for the "mother"). Evans, Over and Manktelow (1993), generalized the previous explanation considering that people reason in order to support their decisions and achieve objectives, and they propose an explanation for the deontic reasoning based on decision theory. The subjective utilities and the perceived objectives are crucial pragmatic factors which modulate the selection of cards (see Kirby, 1994, who based himself on the subjective expected utility theory to explain performance in the selection task).

Similar results to those of Manktelow and Over (1991) were observed in the work of Politzer and NguyenXuan (1992) and Gigerenzer and Hug (1992); the latter suggest the term "social perspective effect", which occurs when the subjects are induced to select "p and not-q" or "not-p and q", by varying the perspective from which they are reasoning.

In conclusion, the most effective versions of the selection task may be related to deontic forms as opposed to indicative forms. Does this mean that the subjects' responses are modulated exclusively by the deontic or indicative nature of the task? When we compare performance on indicative tasks with that on deontic tasks, does the subject transition from an inept reasoner being to a pragmatic virtuoso? (see Girotto, Kemmelmeier, Sperber, \& van Der Henst, 2001). Some of the principal lines of research which have attempted to respond to these and other questions regarding deontic reasoning and the selection task will be presented hereinafter (see Table 1).

\subsection{Is Deontic Reasoning "Special"?}

When subjects are presented with a deontic version of the task, they generally select the cards that coincide with the formally correct ones. Sometimes this result has been interpreted as evidence that there is a special innate capacity underlying deontic reasoning. This is what is known as the "deontic advantage", defended by authors such as Cummins (1996a, 1996b, 2013), or Harris and Nuñez (1996). However, such an assertion has been questioned by other researchers, such as Astington and Dack (2013); Bucciarelli and Johnson-Laird (2000); Dack and Astington (2011); Veleiro, Peralbo and García-Madruga (1998), among others.

According to Cummins (1996a, 1996b) the differences in performance between deontic and indicative tasks have their origin in the type of specific control and innate strategies which are used in each of them. In particular, 
Table 1. Empirical research on the importance of semantic and pragmatic factors in the selection task.

\begin{tabular}{|c|c|}
\hline Authors & Rule-Example \\
\hline Wason \& Shapiro (1971) & "Everytime I go to Manchester I travel by car". \\
\hline $\begin{array}{l}\text { Johnson-Laird, Legrenzi, \& } \\
\text { Legrenzi (1972) }\end{array}$ & $\begin{array}{l}\text { "If a letter is sealed, then it has a } \\
50 \text { lira stamp on it". }\end{array}$ \\
\hline Manktelow \& Evans (1979) & "If I eat haddock, then I drink gin". \\
\hline Griggs \& Cox (1982) & $\begin{array}{l}\text { "If a person is drinking beer, then the } \\
\text { person must be over } 19 \text { years of age". }\end{array}$ \\
\hline Cheng \& Holyoak (1985) & $\begin{array}{l}\text { "If the form says ENTERING on one side, } \\
\text { then the other side includes CHOLERA } \\
\text { among the list of diseases". }\end{array}$ \\
\hline Cosmides (1989) & $\begin{array}{l}\text { "If a man eats cassava root, } \\
\text { then he has a tattoo on his face". }\end{array}$ \\
\hline $\begin{array}{c}\text { Asensio, Martín Cordero, } \\
\text { García-Madruga, \& Recio (1990) }\end{array}$ & $\begin{array}{l}\text { "If a person is driving a car, } \\
\text { then he must be over } 18 \text { years old". }\end{array}$ \\
\hline Manktelow \& Over (1991) & $\begin{array}{l}\text { "If you tidy up your room, } \\
\text { then you may go out to play". }\end{array}$ \\
\hline Gigerenzer \& Hug (1992) & $\begin{array}{l}\text { "If an employee works on the weekend, then } \\
\text { that person gets a day off during the week". }\end{array}$ \\
\hline
\end{tabular}

Holyoak \& Cheng (1995)

Valiña, Seoane, Ferraces, \& Martín (1995)

Love \& Kessler (1995)

Valiña, Seoane, Ferraces, \& Martín (1998)

Stanovich \& West (1998)

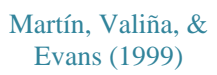

Staller, Sloman, \& Ben-Zeev (2000)

Valiña, Seoane, Ferraces, \& Martín (2000)

Almor \& Sloman (2000)

Girotto, Kemmelmeier, Sperber, \& van der Henst (2001)
"If a car owner installs a new catalytic converter, then that person gets a subsidy".

"If a Wasit card has A on one side, then it must have a 3 on the other side". "If a person is sitting in the front seat of a car, then that person must be over 12 years of age".

"If there are Xow, then there must be a force field”. "If a person is riding a motorcycle
then he must wear a helmet".

"If 'Baltimore' is on one side of the ticket then 'plane' is on the other side of the ticket".

"If a card has a bricklayer written on one side, then it must have/has hard hat written on the other side".

"If a Hare Mantra child is at least 8 years old, then that child performs well the 8-years intelligence test”.

"If a person is more than 18 years old, then he has the right to vote".

"If an employee gets a day off during the week, then that employee must have worked on the weekend".

"If a person travels to any East African country, then that person must be immunized against cholera”.

\section{Result-Explanation}

Facilitation of thematic content.

Facilitation of thematic content.

No thematic facilitation in arbitrary relationship.

Facilitation by content-experience relationship.

Facilitation by activation of permission rules.

Facilitation by reformulation of the rule as cost-benefit and application of cheater-detector algorithm.

Execution by double syntactic-semantic processing.

Selection of cards which breaks the rule. Child: "p and not-q". Mother: "not-p and q".

Perspective effect and cheater-detector algorithm modulate the selection (employee: "p and not-q"; employer: “not-p and q”).

Pragmatic Schemas Theory explains the role of content and context. Rights and duties: complementary terms.

Better performance in thematic version. Facilitation of violation instructions. Individual differences

The context: key if it suggests the activation of counterexamples.

Interactive effect instructions and content. Superior logical indexes in deontic versions.

Better performance in deontic version. Individual differences.

Effect of scenario in deontic problems. Better performance in permission or obligation rules.

Perspective effect does not require deontic context. Execution according to activation of counterexamples.

Facilitation of violation instructions. Better performance in thematic-obligation task. Individual differences.

Looks for rule-history coherence.

The context expressed in the text modulates the relevancy to make inferences. 
Continued

Handley, Feeney, \& Harper (2002)

Ayal \& Klar (2014)

Thompson, Plowright, Attance, \& Caza (2015)
"If a customer lives in Tavistock then they pay the reduced tariff".

"If a customer lives in Plymouth/Totnes then they pay the reduced tariff".

"If you buy my miracle medicine for $\$ 12.50$, you will be cured in less than ten days". "If you give me $\$ 60$, then I will have the furniture delivered and assembled in your home”.

"If it is the first day of the month, then there must be pancakes for lunch". "If the child takes a cookie then the child must have earned a gold star sticker”.
Selection of cards influenced by presence of a second rule.

Different cheating ploys modulate the selection. Key: necessity/sufficiency of the cost-benefit relationship.

Interaction type of problem ("cheater or non cheater") and parental connection with the child (existent or non-existent).

in deontic tasks, search strategies are used to detect possible violations of the rule, while in indicative tasks, verification strategies are used (see, however, Veleiro, Peralbo, \& García-Madruga, 1998, for a reply of Cummins (1996a), in which the authors did not register the confirmatory search strategy in indicative contexts). Using toys in place of cards and a simplified version of the Wason's selection task (RAST), Cummins (1996a) observed that 3 - 4-year-old children presented this innate capacity (see also Harris \& Nuñez, 1996: Experiment 4). From a different perspective, Astington and Dack (2013), Dack and Astington (2011) have considered that it is the context, both linguistic and extralinguistic, which determines if a statement is interpreted as a rule, which may be obeyed or disobeyed, or as an inference, which may be true or false.

In a great majority of studies, the deontic selection task has provided little empirical evidence of deductive reasoning, as opposed to the indicative version. An alternative explanation comes from research on the study of individual differences (see for example, Stanovich \& West, 1998). These authors have considered that subjects' ability to solve deontic versions was linked more to the influence of pragmatic, rapid and automatic processes, than to their intellectual ability or to the presence of innate strategies. Factors such as intelligence or cognitive style have proved good predictors of performance in indicative versions of the task, such as the original abstract version, which requires an explicit and conscious reasoning process (see Newstead, Handley, Harley, Wright, \& Farelly, 2004; Stanovich \& West, 1998; Valiña, Seoane, Ferraces, \& Martín, 1995, 2000, for some studies on individual differences in reasoning with the selection task).

Some authors consider that the means to understanding the mechanisms and functions of reasoning, must be the context of the task (Osman, 2014). Different studies in which it was empirically ratified that this variable was a key modulating factor in the selection of cards will be presented hereinafter.

\section{The Context Effect}

There is an increasing number of authors who propose different pragmatic aspects as the keys which allow for an explanation of performance, both in indicative and in deontic versions of the task. In this sense, it appears that the mere presence of a verb such as "must" does not bestow a deontic nature to the statement, nor does it explain the differences between both versions. In effect, deontic conditionals may have a different role depending on the context in which they are proposed.

Authors such as Almor and Sloman (1996, 2000); Girotto et al. (2001); Staller, Sloman and Ben-Zeev (2000), among others, designed different empirical studies in which it was considered that the difference between correct and incorrect selection was modulated more by factors relating to context than by the mere deontic or indicative nature of the statement. Almor and Sloman (2000) designed research based on the "reversed-perspective paradigm", using narrative texts. They used the "day-off version", in which the following rule of permission was included: "If an employee gets a day off during the week, then that employee must have worked on the weekend". The task was contextualized in a story which described the obligation of a company to give an employee one week day off when he had worked at the weekend. The subjects constructed a representation of the problem with a rule that was compatible with the whole task and, in consequence, they processed it as an obligation. In effect, there was a tendency to increase the amount of information presented by using general knowledge and by searching for coherence in the text. In this sense, when the subject reads a text, they construct a rich and coherent representation which goes beyond the same (De Vega, 1998). See also Haigh and Stewart (2011); Martín, Valiña, 
Seoane and Ferraces (1998); Valiña (1985); Valiña and De Vega (1988); Valiña, Martín, Gehring and Seoane (2015); Valiña, Seoane, Ferraces and Martín (1997), for other studies which analyse the role that the congruence or coherence of a text plays in subjects' reasoning in different deductive reasoning tasks.

Another empirical investigation along the same lines, is the work of Girotto et al. (2001), who propose that deontic rules may also have a descriptive claim. They used two deontic and two descriptive versions and the same rule in all of them: "If a person travels to any East African country, then that person must be immunized against cholera”. They included this rule in a narrative text, changing the story in which the rule was contextualized and the cards presented, from one version to another. According to the relevance theory, linguistic comprehension processes determine intuitions of relevance, that modulate the card selection, and "these intuitions can be manipulated through alterations of content and context” (Girotto et al., 2001: p. 75).

Most research which has analysed the role of perspective in reasoning with the selection task, has included deontic conditionals and rules which reflect social contracts or conventions. However, studies have also been designed in which the effect of perspective on reasoning, using non-deontic rules, has been ratified (for example, causal rules: Beller \& Spada, 2003, or Fairley, Manktelow, \& Over, 1999, among others). According to Beller and Spada (2003), the key to explaining performance in this task lies in the difference between content competency and form competency. The former refers to the ability to reason in accordance with social or causal rules or conventions. The latter is the ability to reason in accordance with the rules of logic. The authors found evidence of both types of competency by using selection tasks based on violations of the rule, with both causal and deontic statements. Within the framework of deontic conditionals, Beller (2008) differentiates between two types: strong and weak deontic conditionals, depending on whether or not they consider social limits on behaviour, such as prohibitions and permissions respectively.

Other authors, such as Staller et al. (2000), have considered that "different modal operators exist to express necessity, possibility, certainty, probability, obligation and so on, and each supports different inferences" (p. 404). The authors analysed the effect of perspective in both versions of the problem, deontic and indicative, and observed that this effect was modulated by the elicitation of counterexamples based on descriptions of the task. Context was key to the differences between both types of conditionals. Other studies, in previous decades, highlighted the importance of the ability to activate counterexamples, as another key factor in indicative versions of the task (Green, 1995; Green \& Larking, 1995 or Love \& Kessler, 1995, among others). In effect, "the ability to understand the premises, together with the ability to find counterexamples, accounts for the ability to reason, both deontically and factually” (Bucciarelli \& Johnson-Laird, 2000: pp. 227-228).

Therefore, these empirical studies appear to suggest that reasoning using deontic versions of the selection task were modulated by the same factors as in non-deontic versions, being the context of the problem a key variable in the selection of cards.

Another important pragmatic aspect is the relationship that the subject may activate based on the statement, relying on their conceptual system and on their experience. In this sense, different empirical studies have analysed the role of the perceived necessity and sufficiency implicit in the statement, in performance with the four card problem.

\section{Necessity and Sufficiency in the Selection Task}

The key to reasoning could lie in the condition of necessity or sufficiency inherent in the conditional statements. In a selection task, casting doubt on sufficiency of a condition, leads to a higher frequency of "p and not-q" responses, while questioning the necessity leads to "not-p and q" cards (see for example Thompson, 1995 or Fairley et al., 1999).

Ahn and Graham (1999: Experiment 1), used three thematic versions and one abstract version and they manipulated the necessity/sufficiency relationship by means of the story presented to the subjects and the modal verb used in the statement. They observed that the most frequent response was the normative, independently of the content of the rule (experiment 1) and without taking the subjects' perspective into account (experiment 2).

The discussion on the necessity/sufficiency of the conditional as a modulating factor in the selection of cards, was extended by Hilton, Kemmelmeier and Bonnefon (2005). The authors pointed out the pragmatic use of deontic conditionals as they called "conditional directives". This involves statements which are intended to influence the actions other people have in mind when they express them, for example, a promise, a threat, etc. (Evans \& Twyman-Musgrove, 1998; Newstead, Ellis, Evans, \& Dennis, 1997 or Valiña, Martín, \& Seoane, 2014, 
among others, analysed the effect of this type of statements by using other conditional reasoning tasks).

Therefore, the protagonists' beliefs, desires and intentions, inferred by the reasoner, seem to play a fundamental role in performance (see for example Haigh \& Bonnefon, 2015, for a study on how readers infer intentions based on the desires and beliefs of others, via their eye-movements; see also Hilton, 2016; Hilton, Charalambides, \& Hoareau, 2016).

The empirical research presented thus far has shown that when subjects reason over the selection task, the cards they select and, in short, the conclusions they produce, could be modulated by semantic and pragmatic factors. How has this question been dealt with based on the principal theories of human reasoning?

\section{Semantic and Pragmatic Factors in the Selection Task: Main Theoretical Explanations}

Some authors have considered that the facilitation effect in the selection task may occur in some contexts in which the subjects have no experience with the content of the problem. However, they do have experience in analogous contexts which allows them to activate a series of "abstract knowledge structures". This is the proposal defended by the Theory of Pragmatic Reasoning Schemas (Cheng \& Holyoak, 1985, 1989; Cheng, Holyoak, Nisbett, \& Oliver, 1986; Holyoak \& Cheng, 1995) and the Social Contract Theory (Cosmides, 1985; 1989; Cosmides \& Tooby, 1992).

From a different perspective, it is suggested that subjects reason elaborating semantic representations of objects and situations in the real world, which they construct based on the information given in the task and by using their knowledge of the world. This is the position defended by the Mental Models Theory (Johnson-Laird, 1983; Johnson-Laird \& Byrne, 1991, 2002).

Finally, the Heuristic-Analytic Theory (Evans, 1984, 1989, 2006) proposes that subjects reason over information that they have previously selected in a non-conscious manner.

How reasoning on the selection task has been addressed from these theoretical approaches will now be explained.

\subsection{The Theory of Pragmatic Reasoning Schemas}

From this perspective, subjects reason by activating a series of "knowledge packages" learnt from experience or pragmatic schemas, which express permission, obligation or causal relationships. For Cheng and Holyoak (1985), the content effect in the selection task is related to the activation of the four production rules included in the permission schema, according to which, "If an action is to be taken then a precondition must be satisfied". For example, the thematic facilitation registered in the "drinking age rule" (Griggs \& Cox, 1982) has been explained by these authors, based on the activation of permission schema. Specifically, "if a person is drinking beer (action) then they must be over 19 years of age (precondition)". In this context, breaking the rule would mean carrying out the action without fulfilling the precondition (and therefore selecting, in general terms, " $\mathrm{p}$ and not-q"). Cheng and Holyoak also produced a new version of the selection task, related to immigration rules at an airport: "If it says ENTER on one side, then the other side must include CHOLERA on the list of diseases". The task was presented to the subjects in two versions: rational, in which it was explained to them that "they should ensure that the passengers who entered were protected against the disease", and the non-rational version, which did not include this specification. The percentage of correct selections decreased from $90 \%$ in the first version to $60 \%$ in the second. Other researchers who have supported the facilitation effect with the permission schema are Girotto, Mazzocco and Cherubini, 1992; Griggs and Cox, 1993; Jackson and Griggs, 1990; Kroeger, Cheng and Holyoak, 1993, among others.

According to Evans and Over (2004), the pragmatic schema theory does not explain the role of deontic conditionals, but it was "simply designed to account for responses in the selection task" (p. 84). Another theoretical approach which has explained reasoning using specific domain rules, in this case innate, is the social contract theory.

\subsection{The Social Contract Theory}

According to Cosmides (1985, 1989); Cosmides \& Tooby (1992, 2013); Fiddick, Cosmides, \& Tooby (2000), subjects have a series of social contract algorithms which allow them to reason in social exchange contexts and 
to detect the people who cheat. In particular, when subjects reason with the selection task, they try to reformulate the rule in terms of a social exchange: "if you take a benefit then you pay a cost". They immediately apply the "cheater detector algorithm", looking for those subjects who obtain the benefit without paying the cost; in general terms selecting " $p$ and not-q" cards.

In the version about the behaviour of aboriginal people, devised by the author, the subjects received a text in which they were asked to imagine that they were a member of the polynesian culture and they were given the rule: "If a man eats cassava root then he has a tattoo on his face". In this version, $75 \%$ of the responses registered were correct compared to around $25 \%$ with a descriptive version. This result was explained based on the reformulation of the rule in terms of cost-benefit and the activation of the "cheater detector algorithm", which would mean "eating cassava root without having a tattoo on the face" (obtaining the benefit without paying the cost), that is selecting, in general, the "p and not-q cards".

In daily life, people can "cheat" and commit infractions for different reasons, which may be more or less serious. This type of pragmatic aspects have been analysed within the framework of the selection task. For example, Cosmides and Tooby (1992), or Fiddick (2004), observed that "cheat detection" improved when the scenario was related to intentional violations of the rule, as opposed to when the violation was presented as accidental. On the other hand, there are different types of cheating, depending on the necessity-sufficiency of the perceived relationship between cost-benefit, which could lead to different selections being made (Ayal \& Klar, 2014; see Table 1).

However, people do not always "cheat"; on occasion, they are altruistic and carry out laudable actions in benefit of others, in spite of the personal cost to themselves. One particular line of research which has arisen in this context, has analysed the differences in performance with the selection task among altruistic and cooperative subjects (those who fulfil their obligations in a reciprocal exchange). In general, the subjects' task in these studies was to specify whether somebody was being cooperative or altruistic; see for example Fiddick and Elrich (2010) or Thompson, Plowright, Atance and Caza (2015).

In general terms, one of Leda Cosmides' principal critiques, revolves around the nature of the experiments she designs, in which she uses very long and complex verbal scenarios (Evans, 2007) and instructions which change the nature of the task, with regard to the original version (Sperber \& Girotto, 2002). Likewise, from critical stances, it has been proposed that there other versions of the task which do not appear liable to be explained within the framework of the social contract theory (for example, the "hospital version", using the rule: "if you clear up spilt blood, then you must wear rubber gloves" (Manktelow \& Over, 1990). This critique lead Fiddick, Cosmides and Tooby (2000), to propose a new schema for a new domain related to precautions. However, Manktelow and Over opted for an explanation that was closer to the mental models theory.

\subsection{The Theory of Mental Models}

For Johnson-Laird (1983); Johnson-Laird and Byrne (1991, 2002), subjects reason by elaborating semantic representations or mental models, which reflect the meaning of the premises. This theory proposes that there are several reasoning stages that subject go through in order to draw the conclusion in a reasoning problem. First, the comprehension stage, based on the interpretation of the problem content, derived from current experience and background knowledge, to understand its premises. This process give the subjects a set of mental models of the problem's elements. From this, the subject pass to the description stage, in which he try to draw a conclusion. Finally, he validate it by searching for alternative models that defeat it or counterexamples. If he do find out one, he go back to the previous stage and see if he can formulate a conclusion that is true in all of the models.

One of the basic principles of this theory is that subjects tend to represent as much implicit information as is possible, only reasoning over the models that are explicitly represented. In the case of the selection task, the conditional rule "if a card has a consonant on one side, then it has an odd number on the other side", carries the explicit initial representation:

$$
\text { [consonant] odd }
$$

where the three dots “...” represent the implicit models. Subjects could consider only the cards that are explicitly represented in their models of the rule, which could lead them to commit matching bias (selection of: consonant, odd).

In order to reach the correct conclusion, it is necessary that the three models of the conditional to be explicitly 
represented (and therefore, the subjects will perceive the need to turn over the negated consequent):

$\begin{array}{ll}\text { consonant } & \text { odd } \\ \text { consonant } & \text { odd } \\ \text { consonant } & \text { odd }\end{array}$

One of the general predictions of this theory is: "any manipulation that draws attention to counter-examples should improve performance” (Johnson-Laird \& Byrne, 1991: pp. 80-81). Likewise, any manipulation which minimizes the load in the operative memory, should also improve performance (Johnson-Laird, 1995).

According to the models theory, subjects tend to represent what is true, but no what is false. However, in the selection task representing what is false is key to making the correct selection (Santamaría \& Espino, 2006). In this sense, when what would be false in a factual relationship, or what would violate the rule in a deontic relationship is made explicit, this could improve performance in the selection task.

According to Johnson-Laird and Byrne (2002), indicative and deontic conditionals lead to equivalent semantic interpretations: the indicative conditionals describe physical possibilities and impossibilities and the deontic conditionals describe deontic possibilities and impossibilities, even though the empirical evidence seems to show that deontic statements make what is impossible more prominent than do factual ones (Bucciarelli \& Johnson-Laird, 2000, 2005).

For years, one of the principal critiques of the mental model theory was the lack of specificity regarding what type of mechanism modulate the content and context effects on reasoning. In this sense, Johnson-Laird and Byrne (2002) have proposed semantic and pragmatic modulation mechanisms to explain the elaboration of alternative mental models or to block their construction (see Johnson-Laird, 2000, 2012, 2013 for reviews of this theory).

The following theory has its origins in the Wason's selection task: the Heuristic-Analytic theory.

\subsection{The Heuristic-Analytic Theory}

This theoretical approach has its origins in the dual process theory (Evans \& Wason, 1976; Wason \& Evans, 1975), which emerged precisely to explain the discrepancies in the Wason task between the subjects' introspective reports and the experimental evidence of bias. In its original form, the heuristic-analytic theory (Evans, 1984 , 1989) considered two different phases in order to explain the reasoning process: an initial phase of heuristic processing, which leads to selecting the relevant information on what is to be reasoned in a second phase of reasoning or analytic phase. This initial selection is modulated by linguistic, semantic and/or pragmatic variables, which could lead subjects to make mistakes in the heuristic phase, focussing their attention on irrelevant aspects of the task or not considering relevant aspects. The second phase includes an unspecific reasoning mechanism, although closer to the elaboration of mental models than to the activation of formal rules.

The heuristic-analytic theory has been revised (Evans, 2006), to include the possible existence of bias in the analytic stage also. It would seem that both types of heuristic and analytic processing are influenced by beliefs, although in different ways (for a more detailed explanation, see Weidenfeld, Oberauer, \& Hörnig, 2005).

This theoretical approach falls within the framework of the so-called double process theories (specifically, Evans \& Over, 1996; Evans \& Stanovich, 2013). Evans and Over (1996), propose the existence of two different cognitive systems: System 1, of an implicit type, which recovers and applies knowledge quickly and automatically, and System 2, or an explicit system, which supports hypothetical thinking. Both systems may be the origin of bias, which appears to especially affect subjects of lesser cognitive ability (Stanovich, 1999). See Evans, 2000, 2012, 2013 for reviews of this theoretical perspective.

According to Evans and Clibbens (1995), beliefs may lead subjects to focus their attention on particular cards, which are selected based on criteria of relevance, more so than on any logical reasoning process. In this sense, Sperber, Cara and Girotto (1995), propose the theory of relevance to explain performance on the selection task, and define what is relevant as that which involves low cognitive effort and high cognitive effect. According to the authors, reasoning on the task is modulated by the subjects' perspectives on what is relevant, depending on the content and context of the task (see Evans, 1995; Sperber, Cara, \& Girotto, 1995).

One of the debates proposed within the context of this theory refers to the following question: When subjects are faced with the four-card task, "do they decide on which cards to select before they think about them?" (Evans, 1996) or, on the contrary, "do they think before making the selection?” (Handley, Newstead, \& Neilens, 2011). In connection to this topic, in the past few decades a theoretical debate has been proposed regarding what measures would be the most ideal in order to go into depth into the study of reasoning. In particular, a series of 
empirical works have been developed which propose new indices, such as the inspection times, eye-movements or neural correlates. Along these lines, see Ball (2011, 2014); Ball, Lucas, Miles and Gale (2003); Cutmore, Halford, Wang, Ramm, Spokes, \& Shum (2015); Evans (1996); Evans and Ball (2010), Lucas and Ball (2005); Roberts (1998); Roberts and Newton (2001, 2011). In more general terms, see De Neys and Osman (2014), for a recent publication about new methods of research on reasoning.

\section{Conclusion}

Research on the effect of facilitation in the selection task has put forth two important issues: 1) it does not necessarily involve an improvement in logical performance, and 2) it is not simply thematic facilitation. The existence of a key factor in explaining performance is not defended, like what had occurred in the 1970's regarding the content of the rule. There are different variables which may interact and explain reasoning on this task. Furthermore, the degree of improvement varies considerably from research to research. In effect, "no manipulation yields perfect selections in one condition and wholly erroneous selections in another" (Johnson-Laird, 1995: p. 136). Perhaps because, as Beller and Spada (2003) propose, "the extent to which a content effect arises depends in part on task-specific factors” (p. 367). Already in the 90’s, Asensio, Martín Cordero, García-Madruga and Recio (1990) had anticipated that the matter of the quality and intensity of the influence of the content was a problem that would take some time to solve.

The selection task requires understanding a conditional statement as well as elaborating and verifying hypotheses on what may be on the other side of each card. In particular, the conditional is ambiguous by nature and subjects on occasion interpreting it incorrectly. However, the material implication may not be the only problem, as the so-called "deductive illusions" also occur in other types of statements (Johnson-Laird \& Savary, 1999; Santamaría \& Johnson-Laird, 1998, 2000). According to Stanovich (2015) the key is: "When reasoning hypotheticallly, a person must be able to represent a belief as separate from the world it is representing” (p. 149).

An important part of empirical research on the selection task appears to indicate the plasticity of reasoning towards factors related to content, context and empirical knowledge. In this sense, allowing us to finish this study using the words of Byrne (2016) on counterfactual conditionals, for the conditional with the four-card problem: knowledge affects the plausibility of a conditional through the semantic and pragmatic modulation of the mental representation of alternative possibilities.

\section{References}

Ahn, W., \& Graham, L. M. (1999). The Impact of Necessity and Sufficiency Information in the Wason Four-Card Selection Task. Psychological Science, 10, 237-242. http://dx.doi.org/10.1111/1467-9280.00143

Almor, A., \& Sloman, S. A. (1996). Is Deontic Reasoning Special? Psychological Review, 103, 374-380. http://dx.doi.org/10.1037/0033-295X.103.2.374

Almor, A., \& Sloman, S. A. (2000). Reasoning versus Text Processing in the Wason Selection Task: A Nondeontic Perspective on Perspective Effects. Memory \& Cognition, 28, 1060-1070. http://dx.doi.org/10.3758/BF03209354

Asensio, M., Martín Cordero, J., García Madruga, J. A., \& Recio, J. (1990). “Ningún iroqués era mohicano”: La influencia del contenido en las tareas de razonamiento lógico. Estudios de Psicología, 11, 35-60. http://dx.doi.org/10.1080/02109395.1990.10821142

Astington, J. W., \& Dack, L. A. (2013). Development of the Deontic Advantage in Reasoning: Reply to Cummins. Journal of Experimental Child Psychology, 116, 770-773. http://dx.doi.org/10.1016/j.jecp.2013.03.001

Ayal, S., \& Klar, Y. (2014). Detecting Varieties of Cheating: How Do People Navigate between Different Cheating Ploys? Thinking \& Reasoning, 20, 51-76. http://dx.doi.org/10.1080/13546783.2013.798595

Ball, L. J. (2011). The Dynamics of Reasoning. Chronometric Analysis and Dual-Process Theories. In K. Manktelow, D. Over, \& S. Elqayam (Eds.), The Science of Reason: A Festschrift for Jonathan St B. T. Evans (pp. 283-307). Hove and New York: Psychology Press.

Ball, L. J. (2014). Eye-Tracking and Reasoning: What Your Eyes Tell about Your Inferences. In W. De Neys, \& M. Osman (Eds.). New Approaches in Reasoning Research. Current Issues in Thinking and Reasoning (pp. 51-69). London and New York: Psychology Press.

Ball, L. J., Lucas, E. J., Miles, J. N. V., \& Gale, A. G. (2003). Inspection Times and the Selection Task: What Do EyeMovements Reveal about Relevance Effects? Quarterly Journal of Experimental Psychology Section A: Human Experimental Psychology, 56, 1053-1077. http://dx.doi.org/10.1080/02724980244000729 
Beller, S. (2008). Deontic Norm, Deontic Reasoning, and Deontic Conditionals. Thinking \& Reasoning, 14, 305-341. http://dx.doi.org/10.1080/13546780802222258

Beller, S. (2010). Deontic Reasoning Reviewed: Psychological Questions, Empirical Findings, and Current Theories. Cognitive Processing, 11, 123-132. http://dx.doi.org/10.1007/s10339-009-0265-z

Beller, S., \& Spada, H. (2003). The Logic of Content Effects in Propositional Reasoning: The Case of Conditional Reasoning with a Point of View. Thinking and Reasoning, 9, 335-378. http://dx.doi.org/10.1080/13546780342000007

Bucciarelli, M., \& Johnson-Laird, P. N. (2000). Is There an Innate Module for Deontic Reasoning? In J. A. García-Madruga, N. Carriedo, \& M. J. González-Labra (Eds.), Mental Models in Reasoning (pp. 227-239). Madrid: Universidad Nacional de Educación a Distancia. Varia.

Bucciarelli, M., \& Johnson-Laird, P. N. (2005). Naïve Deontics: A Theory of Meaning, Representation, and Reasoning. Cognitive Psychology, 50, 159-193. http://dx.doi.org/10.1016/j.cogpsych.2004.08.001

Byrne, R. M. J. (2016). Counterfactual Thought. Annual Review of Psychology, 67, 135-157. http://dx.doi.org/10.1146/annurev-psych-122414-033249

Byrne, R. M. J., \& Johnson-Laird, P. N. (2009). "If” and the Problems of Conditional Reasoning. Trends in Cognitive Science, 13, 282-287. http://dx.doi.org/10.1016/j.tics.2009.04.003

Cheng, P. W., \& Holyoak, K. J. (1985). Pragmatic Reasoning Schemas. Cognitive Psychology, 17, 391-416. http://dx.doi.org/10.1016/0010-0285(85)90014-3

Cheng, P. W., \& Holyoak, K. J. (1989). On the Natural Selection of Reasoning Theories. Cognition, 33, $285-313$. http://dx.doi.org/10.1016/0010-0277(89)90031-0

Cheng, P. W., Holyoak, K. J., Nisbett, R. E., \& Oliver, L. M. (1986). Pragmatic versus Syntactic Approaches to Training Deductive Reasoning. Cognitive Psychology, 18, 293-328. http://dx.doi.org/10.1016/0010-0285(86)90002-2

Cosmides, L. (1985). Deduction or Darwinian Algorithms? An Explanation of the "Elusive" Content Effect on the Wason Selection Task. Unpublished Doctoral Dissertation, Cambridge, MA: Harvard University. (University Microfilms 8602206)

Cosmides, L. (1989). The Logic of Social Exchange: Has Natural Selection Shaped How Humans Reason? Studies with the Wason Selection Task. Cognition, 31, 187-276. http://dx.doi.org/10.1016/0010-0277(89)90023-1

Cosmides, L., \& Tooby, J. (1992). Cognitive Adaptations for Social Exchange. In J. H. Barkow, L. Cosmides, \& J. Tooby (Eds.), The Adapted Mind: Evolutionary Psychology and the Generation of Culture (pp. 162-228). New York: Oxford University Press.

Cosmides, L., \& Tooby, J. (2013). Evolutionary Psychology: New Perspectives on Cognition and Motivation. Annual Review of Psychology, 64, 201-229. http://dx.doi.org/10.1146/annurev.psych.121208.131628

Cummins, D. D. (1996a). Evidence of Deontic Reasoning in 3- and 4-Year-Old Children. Memory \& Cognition, 24, 823-829. http://dx.doi.org/10.3758/BF03201105

Cummins, D. D. (1996b). Evidence for the Innateness of Deontic Reasoning. Mind \& Language, 11, 160-190. http://dx.doi.org/10.1111/j.1468-0017.1996.tb00039.x

Cummins, D. D. (2013). Deontic Reasoning as a Target of Selection: Reply to Astington and Dack. Journal of Experimental Child Psychology, 116, 970-974. http://dx.doi.org/10.1016/j.jecp.2013.03.005

Cutmore, T. R. H., Halford, G. S., Wang, Y., Ramm, B. J., Spokes, T., \& Shum, D. H. K. (2015). Neural Correlates of Deductive Reasoning: An ERP Study with the Wason Selection Task. International Journal of Psychophysiology, 98, 381-388. http://dx.doi.org/10.1016/j.ijpsycho.2015.07.004

Dack, L. A., \& Astington, J. W. (2011). Deontic and Epistemic Reasoning in Children. Journal of Experimental Child Psychology, 110, 94-114. http://dx.doi.org/10.1016/j.jecp.2011.04.003

De Neys, W., \& Osman, M. (Eds.) (2014). New Approaches in Reasoning Research (Current Issues in Thinking and Reasoning). London and New York: Psychology Press.

De Vega, M. (1998). Perspectivas e inferencias en la comprensión del discurso. In M. D. Valiña, \& M. J. Blanco (Eds.), I Jornadas de Psicología del Pensamiento. Actas (pp. 273-286). Santiago de Compostela: Servicio de Publicaciones de la Universidad de Santiago de Compostela. Cursos e Congresos da USC. № 114. http://hdl.handle.net/10347/11948

Evans, J. St. B. T. (1972). Interpretation and Matching Bias in a Reasoning Task. Quarterly Journal of Experimental Psychology, 24, 193-199. http://dx.doi.org/10.1080/00335557243000067

Evans, J. St. B. T. (1984). Heuristic and Analytic Processes in Reasoning. British Journal of Psychology, 75, 541-468. http://dx.doi.org/10.1111/j.2044-8295.1984.tb01915.x

Evans, J. St. B. T. (1989). Bias in Human Reasoning: Causes and Consequences. Hove, UK: Erlbaum.

Evans, J. St. B. T. (1995). Relevance and Reasoning. In S. E. Newstead, \& J. St. B. T. Evans (Eds.), Perspectives on Thinking and Reasoning. Essays in Honour of Peter Wason (pp. 147-171). UK: Lawrence Erlbaum Associates Ltd. 
Evans, J. St. B. T. (1996). Deciding before You Think: Relevance and Reasoning in the Selection Task. British Journal of Psychology, 87, 223-240. http://dx.doi.org/10.1111/j.2044-8295.1996.tb02587.x

Evans, J. St. B. T. (1998). Matching Bias in Conditional Reasoning: Do We Understand It after 25 Years? Thinking \& Reasoning, 4, 45-110. http://dx.doi.org/10.1080/135467898394247

Evans, J. St. B. T. (2000). Thinking and Believing. In J. A. García-Madruga, N. Carriedo, \& M. J. González-Labra (Eds.), Mental Models in Reasoning (pp. 41-55). Madrid: Universidad Nacional de Educación a Distancia. Varia.

Evans, J. St. B. T. (2006). The Heuristic-Analytic Theory of Reasoning: Extension and Evaluation. Psychonomic Bulletin \& Review, 13, 378-395. http://dx.doi.org/10.3758/BF03193858

Evans, J. St. B. T. (2007). Hypothetical Thinking: Dual Processes in Reasoning and Judgement. Hove, England: Psychology Press.

Evans, J. St. B. T. (2011). The Psychology of Reasoning. Reflections on Four Decades of Research. In K. I. Manktelow, D. E. Over, \& S. Elqayam (Eds.), The Science of Reason: A Festschrift for Jonathan St. B. T. Evans (pp. 423-443). Hove, UK: Psychology Press.

Evans, J. St. B. T. (2012). Dual-Process Theories of Deductive Reasoning: Facts and Fallacies. In K. J. Holyoak, \& R. G. Morrison (Eds.), The Oxford Handbook of Thinking and Reasoning (pp. 115-133). New York: Oxford University Press.

Evans, J. St. B. T. (2013). Reasoning. In D. Reisberg (Ed.), The Oxford Handbook of Cognitive Psychology (pp. 635-649). New York: Oxford University Press.

Evans, J. St. B. T., \& Ball, L. J. (2010). Do People Reason on the Wason Selection Task? A New Look of the Data of Ball et al. (2003). The Quarterly Journal of Experimental Psychology, 63, 434-441. http://dx.doi.org/10.1080/17470210903398147

Evans, J. St. B. T., \& Clibbens, J. (1995). Perspective Shifts on the Selection Task: Reasoning or Relevance? Thinking \& Reasoning, 1, 315-371. http://dx.doi.org/10.1080/13546789508251505

Evans, J. St. B. T., \& Frankish, K. (2009). In Two Minds: Dual Processes and Beyond. Oxford: Oxford University Press. http://dx.doi.org/10.1093/acprof:oso/9780199230167.001.0001

Evans, J. St. B. T., \& Johnson-Laird, P. N. (2003). Editorial Obituary. Peter Wason (1924-2003). Thinking \& Reasoning, 9, 177-184. http://dx.doi.org/10.1080/13546780244000141

Evans, J. St. B. T., \& Over, D. E. (1996). Rationality and Reasoning. Hove, England: Psychology Press.

Evans, J. St. B. T., \& Over, D. E. (2004). If. Oxford, UK: Oxford University Press. http://dx.doi.org/10.1093/acprof:oso/9780198525134.001.0001

Evans, J. St. B. T., \& Stanovich, K. E. (2013). Dual-Process Theories of Higher Cognition: Advancing the Debate. Perspectives on Psychological Science, 8, 223-241. http://dx.doi.org/10.1177/1745691612460685

Evans, J. St. B. T., \& Twyman-Musgrove, J. (1998). Conditional Reasoning with Inducements and Advice. Cognition, 69, B11-B16. http://dx.doi.org/10.1016/S0010-0277(98)00062-6

Evans, J. St. B. T., \& Wason, P. C. (1976). Rationalisation in a Reasoning Task. British Journal of Psychology, 67, 479-486. http://dx.doi.org/10.1111/j.2044-8295.1976.tb01536.x

Evans, J. St. B. T., Newstead, S. E., \& Byrne, R. M. J. (1993). Human Reasoning. The Psychology of Deduction. Hove: LEA.

Evans, J. St. B. T., Over, D. E., \& Manktelow, K. I. (1993). Reasoning, Decision Making and Rationality. Cognition, 49, 165-187. http://dx.doi.org/10.1016/0010-0277(93)90039-X

Fairley, N., Manktelow, K. I., \& Over, D. E. (1999). Necessity, Sufficiency, and Perspective Effects in Causal Conditional Reasoning. The Quarterly Journal of Experimental Psychology Section A: Human Experimental Psychology, 52, 771-790. http://dx.doi.org/10.1080/713755829

Feeney, A., \& Thompson, V. A. (2014). Reasoning as Memory (Current Issues in Thinking and Reasoning). New York: Psychology Press.

Fiddick, L. (2004). Domains of Deontic Reasoning: Resolving the Discrepancy between the Cognitive and Moral Reasoning Literatures. The Quarterly Journal of Experimental Psychology Section A: Human Experimental Psychology, 57, 447-474. http://dx.doi.org/10.1080/02724980343000332

Fiddick, L., \& Elrich, N. (2010). Giving It All Away: Altruism and Answers to the Wason Selection Task. Evolution \& Human Behavior, 31, 131-140. http://dx.doi.org/10.1016/j.evolhumbehav.2009.08.003

Fiddick, L., Cosmides, L., \& Tooby, J. (2000). No Interpretation without Representation: The Role of Domain-Specific Representations and Inferences in the Wason Selection Task. Cognition, 77, 1-79.

http://dx.doi.org/10.1016/S0010-0277(00)00085-8 
Gigerenzer, G., \& Hug, K. (1992). Domain-Specific Reasoning: Social Contracts, Cheating and Perspective Change. Cognition, 43, 127-171. http://dx.doi.org/10.1016/0010-0277(92)90060-U

Girotto, V., Kemmelmeier, M., Sperber, D., \& van der Henst, J.-B. (2001). Inept Reasoners or Pragmatic Virtuosos? Relevance and the Deontic Selection Task. Cognition, 81, B69-B76. http://dx.doi.org/10.1016/S0010-0277(01)00124-X

Girotto, V., Mazzocco, A., \& Cherubini, P. (1992). Judgments of Deontic Relevance in Reasoning: A Reply to Jackson and Griggs. The Quarterly Journal of Experimental Psychology Section A: Human Experimental Psychology, 45, 547-574. http://dx.doi.org/10.1080/14640749208401333

Green, D. W. (1995). Externalization, Counter-Examples and the Abstract Selection Task. The Quarterly Journal of Experimental Psychology Section A: Human Experimental Psychology, 48, 424-446. http://dx.doi.org/10.1080/14640749508401398

Green, D. W., \& Larking, R. (1995). The Locus of Facilitation in the Abstract Selection Task. Thinking \& Reasoning, 1, 183-199. http://dx.doi.org/10.1080/13546789508251503

Griggs, R. A. (1984). Memory Cueing and Instructional Effects on Wason’s Selection Task. Current Psychology, 3, 3-10. http://dx.doi.org/10.1007/BF02686552

Griggs, R. A., \& Cox, J. A. (1982). The Elusive Thematic Materials Effect in Wason's Selection Task. British Journal of Psychology, 73, 407-420. http://dx.doi.org/10.1111/j.2044-8295.1982.tb01823.x

Griggs, R. A., \& Cox, J. A. (1993). Permission Schemas and the Selection Task. The Quarterly Journal of Experimental Psychology Section A: Human Experimental Psychology, 46, 637-651. http://dx.doi.org/10.1080/14640749308401031

Griggs, R. A., \& Jackson, S. L. (1990). Instructional Effects on Responses in Wason’s Selection Task. British Journal of Psychology, 81, 197-204. http://dx.doi.org/10.1111/j.2044-8295.1990.tb02355.x

Haigh, M., \& Bonnefon, J.-F. (2015). Conditional Sentences Create a Blind Spot in Theory of Mind during Narrative Comprehension. Acta Psychologica, 160, 194-201. http://dx.doi.org/10.1016/j.actpsy.2015.05.009

Haigh, M., \& Stewart, A. J. (2011). The Influence of Clause Order, Congruency, and Probability on the Processing of Conditionals. Thinking \& Reasoning, 17, 402-423. http://dx.doi.org/10.1080/10463283.2011.628000

Handley, S., Feeney, A., \& Harper, C. (2002). Alternative Antecedents, Probabilities, and the Suppression of Fallacies in Wason's Selection Task. The Quarterly Journal of Experimental Psychology Section A: Human Experimental Psychology, 55, 799-818. http://dx.doi.org/10.1080/02724980143000497

Handley, S., Newstead, S. E., \& Neilens, H. (2011). Thinking before You Decide on the Selection Task. Matching Bias Requires Analytic Reasoning. In K. I. Manktelow, D. E. Over, \& S. Elqayam (Eds.), The Science of Reason: A Festschrift for Jonathan St B. T. Evans (pp. 167-189). Hove and New York: Psychology Press.

Harris, P. L., \& Nuñez, M. (1996). Understanding of Permission Rules by Preschool Children. Child Development, 67, 1572-1591. http://dx.doi.org/10.2307/1131719

Hilton, D. J. (2016). Pragmatic Approaches to Deontic Conditionals: From Rule Content to Rule Use. In L. Macchi, M. Bagassi, \& R. Viale (Eds.). Cognitive Unconscious and Human Rationality (pp. 183-203). Cambridge, MA: MIT Press.

Hilton, D. J., Charalambides, L., \& Hoareau-Blanchet, S. (2016). Reasoning about Rights and Duties: Mental Models, World Knowledge and Pragmatic Interpretation. Thinking \& Reasoning, 22, 150-183. http://dx.doi.org/10.1080/13546783.2015.1076520

Hilton, D. J., Kemmelmeier, M., \& Bonnefon, J.-F. (2005). Putting Ifs to Work: Goal-Based Relevance in Conditional Directives. Journal of Experimental Psychology: General, 134, 388-405. http://dx.doi.org/10.1037/0096-3445.134.3.388

Holyoak, K. J., \& Cheng, P. W. (1995). Pragmatic Reasoning about Human Voluntary Action: Evidence from Wason Selection Task. In S. E. Newstead, \& J. St. B. T. Evans (Eds.), Perspectives on Thinking and Reasoning. Essays in Honour of Peter Wason (pp. 67-89). UK: Lawrence Erlbaum Associates Ltd.

Jackson, S. L., \& Griggs, R. A. (1990). The Elusive Pragmatic Reasoning Schemas Effect. The Quarterly Journal of Experimental Psychology Section A: Human Experimental Psychology, 42, 353-373. http://dx.doi.org/10.1080/14640749008401226

Johnson-Laird, P. N. (1983). Mental Models. Towards a Cognitive Science of Language, Inference and Consciousness. Cambridge, UK: Cambridge University Press.

Johnson-Laird, P. N. (1995). Inference and Mental Models. In S. E. Newstead, \& J. St. B. T. Evans (Eds.), Perspectives on Thinking and Reasoning. Essays in Honour of Peter Wason (pp. 115-146). UK: Lawrence Erlbaum Associates Ltd.

Johnson-Laird, P. N. (2000). The Current State of the Mental Model Theory. In J. A. García-Madruga, N. Carriedo, \& M. J. González-Labra (Eds.), Mental Models in Reasoning (Varia, pp. 17-40). Madrid: Universidad Nacional de Educación a Distancia. Varia.

Johnson-Laird, P. N. (2012). Inference with Mental Models. In K. J. Holyoak, \& R. G. Morrison (Eds.), The Oxford Handbook of Thinking and Reasoning (pp. 134-154). New York: Oxford University Press.

http://dx.doi.org/10.1093/oxfordhb/9780199734689.013.0009 
Johnson-Laird, P. N. (2013). The Mental Models Perspective. In D. Reisberg (Ed.), The Oxford Handbook of Cognitive Psychology (pp. 650-667). New York: Oxford University Press. http://dx.doi.org/10.1093/oxfordhb/9780195376746.013.0041

Johnson-Laird, P. N., \& Byrne, R. M. J. (1991). Deduction. Hove, NJ: LEA.

Johnson-Laird, P. N., \& Byrne, R. M. J. (2002). Conditionals: A Theory of Meaning, Pragmatics and Inference. Psychological Review, 109, 646-678. http://dx.doi.org/10.1037/0033-295X.109.4.646

Johnson-Laird, P. N., \& Savary, F. (1999). Illusory Inferences: A Novel Class of Erroneous Deductions. Cognition, 71, 191-229. http://dx.doi.org/10.1016/S0010-0277(99)00015-3

Johnson-Laird, P. N., Legrenzi, P., \& Legrenzi, M. S. (1972). Reasoning and Sense of Reality. British Journal of Psychology, 63, 395-400. http://dx.doi.org/10.1111/j.2044-8295.1972.tb01287.x

Kirby, K. N. (1994). Probabilities and Utilities of Fictional Outcomes in Wason’s Four Card Selection Task. Cognition, 51, 1-28. http://dx.doi.org/10.1016/0010-0277(94)90007-8

Kroeger, J. K., Cheng, P. W., \& Holyoak, K. J. (1993). Evoking the Permission Schema: The Impact of Explicit Negation and a Violation-Checking Context. The Quarterly Journal of Experimental Psychology Section A: Human Experimental Psychology, 46, 615-635. http://dx.doi.org/10.1080/14640749308401030

Love, R., \& Kessler, C. (1995). Focussing in Wason's Selection Task: Content and Instruction Effects. Thinking \& Reasoning, 1, 153-182. http://dx.doi.org/10.1080/13546789508251502

Lucas, E. J., \& Ball, L. J. (2005). Thinking-Aloud Protocols and the Selection Task: Evidence for Relevance Effects and Rationalisation Processes. Thinking \& Reasoning, 11, 35-66. http://dx.doi.org/10.1080/13546780442000114

Manktelow, K. I., \& Evans, J. St. B. T (1979). Facilitation of Reasoning by Realism: Effect or Non-Effect? British Journal of Psychology, 70, 477-488. http://dx.doi.org/10.1111/j.2044-8295.1979.tb01720.x

Manktelow, K. I., \& Over, D. E. (1990). Deontic Thought and the Selection Task. In K. J. Gilhooly, M. T. G. Keane, R. H. Logie, \& G. Erdos (Eds.), Lines of Thinking: Reflections on the Psychology of Thinking (Vol. 1, pp. 153-164). London: Wiley.

Manktelow, K. I., \& Over, D. E. (1991). Social Roles and Utilities in Reasoning with Deontic Conditionals. Cognition, 39, 85-105. http://dx.doi.org/10.1016/0010-0277(91)90039-7

Manktelow, K. I., \& Over, D. E. (1995). Deontic Reasoning. In S. E. Newstead, \& J. St. B. T. Evans (Eds.), Perspectives on Thinking and Reasoning. Essays in Honour of Peter Wason (pp. 91-114). UK: Lawrence Erlbaum Associates Ltd.

Margolis, H. (1987). Patterns, Thinking, and Cognition: A Theory of Judgment. Chicago, IL: The University of Chicago Press.

Martín, M., \& Valiña, M. D. (2003). Una aproximación histórica al estudio del pensamiento. Revista de Historia de la Psicología, 24, 93-117.

Martín, M., Valiña, M. D., \& Evans, J. St. B. T. (1999). The Role of Scenario, Deontic Conditionals and Problem Content in Wason's Selection Task. European Conference on Cognitive Science. In S. Bagnara (Ed.), Proceedings of the European Conference on Cognitive Science (pp. 259-264). Siena, Italy.

Martín, M., Valiña, M. D., Seoane, G., \& Ferraces, M. J. (1998). Conditional Reasoning with Narrative Contexts: The Role of Semantic and Pragmatic Factors. Fourth Biennial Conference of the Australasian Cognitive Science Society [CD-ROM]. New South Wales, Australia: University of New Castle.

Martín, M., Valiña, M. D., Seoane, G., \& Leirós, L. (May 2008). La tarea de selección de Wason: Pasado y presente. XXI Symposium de la Sociedad Española de Historia de la Psicología, Granada.

Newstead, S. E., Ellis, C., Evans, J. St. B. T., \& Dennis, I. (1997). Conditional Reasoning with Realistic Material. Thinking \& Reasoning, 3, 49-76. http://dx.doi.org/10.1080/135467897394428

Newstead, S. E., Handley, S. J., Harley, C., Wright, H., \& Farelly, D. (2004). Individual Differences in Deductive Reasoning. The Quarterly Journal of Experimental Psychology Section A: Human Experimental Psychology, 57, 33-60. http://dx.doi.org/10.1080/02724980343000116

Nickerson, R. S. (2015). Conditional Reasoning: The Unruly Syntactics, Semantics, Thematics, and Pragmatics of "If”. Oxford: Oxford University Press. http://dx.doi.org/10.1093/acprof:oso/9780190202996.001.0001

Osman, M. (2014). Reasoning Research: Where Was It Going? Where Is It Now? Where Will It Be Going? In W. De Neys, \& M. Osman (Eds.), New Approaches in Reasoning Research. Current Issues in Thinking and Reasoning (pp. 104-123). London and New York: Psychology Press.

Politzer, G., \& Nguyen-Xuan, A. (1992). Reasoning about Conditional Promises and Warnings: Darwinian Algorithms, Mental Models, Relevance Judgements, or Pragmatic Schemas? The Quarterly Journal of Experimental Psychology Section A: Human Experimental Psychology, 44, 401-421. http://dx.doi.org/10.1080/14640749208401292 
Roberts, M. J. (1998). Inspection Times and the Selection Task: Are They Relevant? The Quarterly Journal of Experimental Psychology Section A: Human Experimental Psychology, 51, 781-810. http://dx.doi.org/10.1080/713755787

Roberts, M. J., \& Newton, E. J. (2001). Inspection Times, the Change Task, and the Rapid-Response Selection Task. The Quarterly Journal of Experimental Psychology Section A: Human Experimental Psychology, 54, 1031-1048. http://dx.doi.org/10.1080/713756016

Roberts, M. J., \& Newton, E. J. (2011). Rapid-Response versus Free Time Selection Tasks Using Different Logical Connectives. Journal of Cognitive Psychology, 23, 858-872. http://dx.doi.org/10.1080/20445911.2011.584526

Santamaría, C., \& Espino, O. (2006). Pensar en lo verdadero para seleccionar lo falso. Psicológica, 27, $195-206$.

Santamaría, C., \& Johnson-Laird, P. N. (1998). Ilusiones en el razonamiento proposicional. In M. D. Valiña, \& M. J. Blanco (Eds.), I Jornadas de Psicología del Pensamiento. Actas (pp. 57-64). Santiago de Compostela: Servicio de Publicaciones de la Universidad de Santiago de Compostela. Cursos e Congresos da USC. No 114. http://hdl.handle.net/10347/11929

Santamaría, C., \& Johnson-Laird, P. N. (2000). An Antidote to Illusory Inferences. Thinking \& Reasoning, 6, 313-333. http://dx.doi.org/10.1080/135467800750038157

Sperber, D., \& Girotto, V. (2002). Use or Misuse of the Selection Task? Rejoinder to Fiddick, Cosmides and Tooby. Cognition, 85, 277-290. http://dx.doi.org/10.1016/S0010-0277(02)00125-7

Sperber, D., Cara, F., \& Girotto, V. (1995). Relevance Theory Explains the Selection Task. Cognition, 57, 31-95. http://dx.doi.org/10.1016/0010-0277(95)00666-M

Staller, A., Sloman, S. A., \& Ben-Zeev, T. (2000). Perspective Effects in Nondeontic Versions of the Wason Selection Task. Memory \& Cognition, 28, 396-405. http://dx.doi.org/10.3758/BF03198555

Stanovich, K. E. (1999). Who Is Rational? Studies of Individual Differences in Reasoning. Mahwah, NJ: Erlbaum.

Stanovich, K. E. (2015). Meta-Rationality in Cognitive Science. Journal of Marketing Behavior, 1, 147-156. http://dx.doi.org/10.1561/107.00000009

Stanovich, K. E., \& West, R. F. (1998). Cognitive Ability and Variation in Selection Task Performance. Thinking \& Reasoning, 4, 193-230. http://dx.doi.org/10.1080/135467898394139

Thompson, E. L., Plowright, C. M. S., Atance, C. M., \& Caza, J. S. (2015). Reasoning and Relatedness. Evolution \& Human Behaviour, 36, 38-43. http://dx.doi.org/10.1016/j.evolhumbehav.2014.08.006

Thompson, V. A. (1995). Conditional Reasoning: The Necessary and Sufficient Conditions. Canadian Journal of Experimental Psychology, 49, 1-60. http://dx.doi.org/10.1037/1196-1961.49.1.1

Valiña, M. D. (1985). Una exploración del razonamiento cotidiano con lenguaje natural: Silogismos con cuantificadores probabilísticos. Unpublished Ph.D. Thesis, Tenerife, Spain: Universidad de La Laguna.

Valiña, M. D., \& De Vega, M. (1988). Un estudio experimental del razonamiento cotidiano en tareas de silogismos: Una aproximación pragmática. Cognitiva, 1, 33-62.

Valiña, M. D., \& Martín, M. (2015). Psicología Cognitiva. Perspectiva histórica. Métodos y metapostulados. Madrid: Pirámide.

Valiña, M. D., Martín, M., \& Seoane, G. (2014). Importancia del conocimiento pragmático en inferencia condicional: Una aproximación experimental. Suma Psicólogica, 21, 81-88. http://dx.doi.org/10.1016/S0121-4381(14)70010-4

Valiña, M. D., Martín, M., Gehring, S., \& Seoane, G. (2015). Efecto de factores temáticos y pragmáticos en razonamiento condicional con textos narrativos. Universitas Psychologica, 14, 1155-1166.

Valiña, M. D., Seoane, G., Ferraces, M. J., \& Martín, M. (1995). Tarea de selección de Wason: Un estudio de las diferencias individuales. Psicothema, 7, 641-653.

Valiña, M. D., Seoane, G., Ferraces, M. J., \& Martín, M. (1997). Pragmatic Factors in Conditional Reasoning with Narrative Texts. In M. G. Shafto, \& P. Langley (Eds.), Proceedings of the Nineteenth Annual Conference of the Cognitive Science Society. NJ: LEA. http://hdl.handle.net/10347/13509

Valiña, M. D., Seoane, G., Ferraces, M. J., \& Martín, M. (1998). La tarea de selección de Wason: ¿Efecto del contenido, efecto de las instrucciones o ambos? Estudios de Psicología, 60, 15-34. http://dx.doi.org/10.1174/02109399860341924

Valiña, M. D., Seoane, G., Ferraces, M. J., \& Martín, M. (2000). Conditional Reasoning: The Importance of individual Differences. In J. A. García-Madruga, N. Carriedo, \& M. J. González-Labra (Eds.), Mental Models in Reasoning (pp. 249-267). Madrid: Universidad Nacional de Educación a Distancia. Varia.

Veleiro, A., Peralbo, M., \& García-Madruga, J. A. (1998). Evidencia de “matching bias” en niños de 3 y 4 años. Una réplica a D. D. Cummins (1996). In M. D. Valiña, \& M. J. Blanco (Eds.), I Jornadas de Psicología del Pensamiento. Actas (pp. 97-109). Santiago de Compostela: Servicio de Publicaciones de la Universidad de Santiago de Compostela. Cursos e Congresos da USC. No 114. http://hdl.handle.net/10347/11935 
Wason, P. C. (1966). Reasoning. In B. M. Foss (Ed.), New Horizons in Psychology. Harmondsworth, UK: Penguin.

Wason, P. C. (1968). Reasoning about a Rule. Quarterly Journal of Experimental Psychology, 12, 129-140. http://dx.doi.org/10.1080/17470216008416717

Wason, P. C., \& Evans, J. St. B. T. (1975). Dual Processes in Reasoning? Cognition, 3, 141-154. http://dx.doi.org/10.1016/0010-0277(74)90017-1

Wason, P. C., \& Johnson-Laird, P. N. (1972). Psychology of Reasoning. Structure and Content. Cambridge, MA: Harvard University Press.

Wason, P. C., \& Shapiro, D. (1971). Natural and Contrived Experience in a Reasoning Problem. Quarterly Journal of Experimental Psychology, 23, 63-71. http://dx.doi.org/10.1080/00335557143000068

Weidenfeld, A., Oberauer, K, \& Hörnig, R. (2005). Causal and Noncausal Conditionals: An Integrated Model of Interpretation and Reasoning. The Quarterly Journal of Experimental Psychology Section A: Human Experimental Psychology, 58, 1479-1513. http://dx.doi.org/10.1080/02724980443000719

Yachanin, S. A. (1983). Cognitive Short-Circuit Strategies: The Path of least Resistance in Inferential Reasoning. Unpublished Ph.D. Thesis, Bowling Green, OH: Bowling Green State University.

Yachanin, S. A. (1986). Facilitation in Wason’s Selection Task: Contents and Instructions. Current Psychology, 5, 20-29. http://dx.doi.org/10.1007/BF02686593

Yachanin, S. A., \& Tweney, R. D. (1982). The Effect of Thematic Content on Cognitive Strategies in the Four-Card Selection Task. Bulletin of the Psychonomic Society, 19, 87-90. http://dx.doi.org/10.3758/BF03330048

\section{Submit or recommend next manuscript to SCIRP and we will provide best service for you:}

Accepting pre-submission inquiries through Email, Facebook, Linkedin, Twitter, etc A wide selection of journals (inclusive of 9 subjects, more than 200 journals)

Providing a 24-hour high-quality service

User-friendly online submission system

Fair and swift peer-review system

Efficient typesetting and proofreading procedure

Display of the result of downloads and visits, as well as the number of cited articles

Maximum dissemination of your research work

Submit your manuscript at: http://papersubmission.scirp.org/ 